\title{
神経因性膀胱に対する尿管膀胖新吻合術
}

\author{
一術後水腎症の検討一 \\ 労働福祉事業団総合せき損センター泌尿器科（部長：岩坪暎二） \\ 岡田英一郎 ${ }^{1)}$ 岩坪 暎二 竹原 俊幸2) 玉田 耕治3)
}

\section{FACTORS RELATED TO POSTOPERATIVE HYDRONEPHROSIS FOLLOWING URETERONEOCYSTOSTOMY IN NEUROGENIC BLADDERS}

\author{
Eiichiro Okada, Eiji Iwatsubo, Toshiyuki Takehara and Koji Tamada \\ Department of Urology, Labor Welfare Corporation Spinal Injuries Center \\ (Chief: E. Iwatsubo, M.D.)
}

A total of 68 ureteroneocystostomies performed between 1980 and 1992 in 63 patients with vesicoureteral reflux (UVR) secondary to neurogenic bladder were reviewed to elucidate factors of postoperative hydronephrosis. Urogram, cystogram, and urodynamics were analyzed, and the cases were classified into two types (areflexia, hyperreflexia) of detrusor muscle response. Occurrence or progression of hydronephrosis was demonstrated in 26 operations (complicated group). Compared with the rest (uncomplicated group), significant difference was not observed concerning proportions of vesical deformity, VUR grades, preoperative hydronephrosis, cystometric types and operative factors. In cases of hyperreflexia maximum vesical volume, maximum vesical pressure or maximum urethral pressure was not different between both groups. However in those of areflexia maximum vesical volume of the complicated group was significantly smaller than that of the uncomplicated group (290 $\pm 35 \mathrm{ml}$ vs. $370 \pm 35 \mathrm{ml}, \mathrm{P}=0.03$ ), and the proportion of bladders with compliance less than 10 $\mathrm{ml} / \mathrm{cmH}_{2} \mathrm{O}$ was significantly higher in the complicated group than in the uncomplicated group $(\mathrm{P}=0.05)$ though maximum vesical pressure or maximum urethral pressure was not different. In areflex bladder deformity was observed more in the complicated group than in the uncomplicated group $(\mathrm{P}=0.06)$. Relative inactiveness of detrusor muscle in areflex bladder might render such preoperative findings as vesical deformity, contracted bladder and low compliance more prognosticative of postoperative hydronephrosis than in hyperreflex bladder. During the follow up (6 to 132, mean 42 months) no case showed progression of hydronephrosis or renal deterioration, nor did any case require revisional surgery. This study indicates that ureteroneocystostomy of neurogenic bladder is no more replete with ureteral obstruction than that of primary VUR.

Key words: neurogenic bladder, ureteroneocystostomy, hydronephrosis

要旨：63名の神経因性膀胱による二次性膀朕尿管逆流に対して，1980年から1992年の間に行われた尿管 膀胱新吻合術68例の膀胱造影, 尿路造影, 膀胱尿道内圧測定成績を解析し, 術後の水腎症に関係する要 因を検討した。手術直後の水腎症の出現または増悪は26例に観察された（悪化群）。それ以外の 42 例（非 悪化群）と比較すると膀胱変形, VUR グレード, 術前の水腎症, 膀脱内圧曲線タイプ（areflexia， hyperrefiexia), 手術要因のどれも違いは無かった. Hyperreflexia 例の場合, 最大膀胱容量, 最大膀脱 内圧, 最高尿道内圧は両群間で有意差が無かった。しかし areflexia 例では最大膀胱内圧, 最高尿道内圧 は差が無かったものの, 悪化群の最大膀胖容量 $(290 \pm 35 \mathrm{ml})$ は非悪化群 $(370 \pm 35 \mathrm{ml})$ より有意に小さ く $(\mathrm{p}=0.03), 10 \mathrm{ml} / \mathrm{cmH}_{2} \mathrm{O}$ 以下の低コンプライフンス膀腅の割合は悪化群に有意に多かった（ $\mathrm{p}=$

\footnotetext{
1)現 国立中津病院泌尿器科

2)現 宮崎医科大学泌尿器科

3)現 九州大学医学部泌尿器科
} 
0.05). また膀胼変形例が悪化群に多い傾向があった $(\mathrm{p}=0.06)$. Hyperreflexia では排尿筋の過活動が 術後水腎症に寄与する割合が大きいのに対し Areflexiaではそれがそしいため, 膀胱変形や小容量, 低コ ンプライアンス膀羘が術後水腎症の悪化に直接反映されると推測される. 経過観察中 $(6 \sim 132$ 力月, 平 均42力月）に水腎症や腎瘢痕の進行例や再手術例は認められず，大半例で水腎症は消失した。水腎症に 関して神経因性膀胱の尿管膀胱新吻合術は原発性 VUR の場合と変わらず晚期合併症は少ない。 キーワード：神経因性膀胱, 尿管膀胱新吻合術, 水腎症

\section{緒 言}

神経因性膀胱に合併した二次性膀胼尿管逆流（以下 VUR と略す)は，放置すれば繰り返される腎孟腎炎と 水腎症により腎機能の廃絶を招来しうるといら点で看 過できない，当センターでは低圧排尿管理にしても腎 機能の低下や尿路感染のコントロールできないVUR に対しては, 積極的に尿管膀胱新吻合術を行ってきた。 神経因性膀胱の術後 VUR 再発率は $4 \sim 24 \%$ であり, 原発性 VUR のそれと比べると劣るがその有用性は確 立している(1) 5)12113). いっぽうもら一つの重要な合併 症である水腎症について，詳しく調べた報告は見受け られないようである。そこで今回我々は水腎症に焦点 を絞り，尿管膀羘新吻合術術後の水腎症の出現あるい は増悪に関わる要因について検討した。

対象と方法

調査対象は当センターで1980年 1 月から1992年 6 月 までの間に，尿管膀胱新吻合術を受けた神経因性膀胱 によるVUR 症例の男44名，女19名である(表 1)。手 術時年齢は 5 から69歳，平均33歳であった，原疾患は 頝髄損傷21名, 胸腰酭損傷 19 名, 二分脊椎14名, その

表 1 患者背景と手術術式

\begin{tabular}{|c|c|c|c|}
\hline 性 & $\begin{array}{l}\text { 男 } \\
\text { 女 }\end{array}$ & $\begin{array}{l}\text { 44名 } \\
19 \text { 名 }\end{array}$ & 計63名 \\
\hline 年齢 & & 5 69歳 & 平均33歳 \\
\hline 原疾患 & $\begin{array}{l}\text { 頝髄損傷 } \\
\text { 胸腰髄損傷 } \\
\text { 二分资椎 } \\
\text { その他 }\end{array}$ & $\begin{array}{r}21 \text { 名 } \\
19 \text { 名 } \\
14 \text { 名 } \\
9 \text { 名 }\end{array}$ & 計63名 \\
\hline 逆流尿管 & $\begin{array}{l}\text { 両側 } \\
\text { 片側 }\end{array}$ & $\begin{array}{l}24 \text { 例 } \\
44 \text { 例 }\end{array}$ & $\begin{array}{c}\text { 計 } 68 \text { 例* } \\
\text { 合計92尿管 }\end{array}$ \\
\hline 手術術式 & $\begin{array}{l}\text { Cohen 法 } \\
\text { Politano-Leadbetter 法 } \\
\text { Sampson 法 } \\
\text { Lich-Grégoir 法 } \\
\text { 単純吻合法 }\end{array}$ & $\begin{array}{r}61 \text { 例 } \\
4 \text { 例 } \\
1 \text { 例 } \\
1 \text { 例 } \\
1 \text { 例 }\end{array}$ & 計68例* \\
\hline
\end{tabular}

*：5名の再手術を重複して教える
他の疾患が 9 名であった。この 63 名のらち 3 名は前医 で一度尿管膀胱新吻合術を受けたことがあり，またこ の期間内に 10 名の再発に対して 5 例の再手術が行われ たので, 重複して数えると初回手術が60例, 再手術が 8 例，合計68例となった，逆流尿管で数えると片側が 44例, 両側が24例で, 計92尿管であった. VUR の診断 時から手術までの期間は 1 力月 111力月, 平均 18 力月 であった，当センターでは原則としてVURのみられ る尿管のみ尿管膀羘新吻合術を行っている5)。手術術 式は Cohen 法が61例, Politano-Leadbeetter 法が 4 例, Sampson 法, Lich-Grégoir 法, 単純吻合法が各 1 例であった，我々はVURのグレードが高くても尿管 のテーパリングを必要とする症例は経験しなかった。 ステントは22例（33\%）に使用したが，経尿道留置カ テーテルと同じく 10 日以内に抜去した.

術前状態の評価項目として以下の検査を採用した。 膀胱造影により膀胱变形の有無とVUR のグレードを 調ベた。膀胱変形ありの判定はレントゲン上，単なる 膀胱全体の変形だけでなく cellulesがみられるものと した. VURのグレードは文部省 VUR 研究班の分類に したがってIa〜IVに分類した ${ }^{6)}$. 両側 VUR 例は高い 方のグレードを採用した。静脈性尿路造影 (IVP) で水 腎症性変化について調べた。水腎症の程度については 造影剂の停滞がみられるものを軽度, 腎孟尿管の払張 はあるが腎杯の拡張は軽いものを中等度, 腎杯腎孟尿 管の拡張が著明であるものを高度と 3 段階に評価し た。原則として術前に膀胱内圧測定と尿道内圧測定を 行い, 排尿笳の反射性収縮の有無により areflexia と hyperreflexia の二つに分類した. Hyperreflexia につ いては毎分 $50 \mathrm{ml}$ の生理食塩水を注入してゆき,反射性 收縮が起こったときの量を最大膀胖容量，その時の内 圧を最大膀胱内圧とした．Areflexia については尿が カテーテル周囲から漏れ出し始めたときの量と内圧を 最大膀胼容量, 最大膀胱内圧とした。最大膀胱容量を 最大膀胱内圧から初圧を減じたもので除してコンプラ イアンスを求めた。

手術後の定期検査は直後 (平均 $20 \pm 7$ 日), 約 3 力月, 
6 力月後, 以降半年ないし 1 年毎に膀脱造影, 膀胼内 圧測定, IVPを行った。手術直後の IVP 所見と術前の それとを比較して，水腎症の出現または増悪の見られ た例（水腎症悪化群）と見られなかった例（水腎症非 悪化群）とに分け，その要因について比較検討した。 統計学的検定は $\chi^{2}$ 検定, Fisher 直接確率計算法もし くは Wilcoxon 順位和検定を用い， $5 \%$ 以下を有意差 ありとした。

手術後の経過観察期間は $6 \sim 132$ 力月, 平均 42 力月で あった。

結 果

1）手術要因と水腎症悪化（表 2）

表 2 手術要因と水腎症悪化

\begin{tabular}{|c|c|c|c|c|c|}
\hline 要 & 因 & $\begin{array}{l}\text { 水腎症 } \\
\text { 非䔡化 }\end{array}$ & 水腎症悪化 & 計 & 検定結果 \\
\hline \multicolumn{2}{|c|}{ 一側手術 } & 29 & $\begin{array}{lr}\text { 同側悪化 } & 10 \\
\text { 対側悪化 } & 2 \\
\text { 両側悪化 } & 3\end{array}$ & 44 & \multirow{2}{*}{ N.S. } \\
\hline \multicolumn{2}{|c|}{ 両側手術 } & 13 & $\begin{array}{ll}\text { 一側悪化 } & 4 \\
\text { 両側悪化 } & 7\end{array}$ & 24 & \\
\hline \multicolumn{2}{|c|}{ 初回手術 } & 37 & 23 & 60 & \multirow{2}{*}{ N.S. } \\
\hline \multicolumn{2}{|c|}{ 再手術 } & 5 & 3 & 8 & \\
\hline \multirow{2}{*}{ ステント } & あり & 14 & 8 & 22 & \multirow{2}{*}{ N.S. } \\
\hline & なし & 28 & 18 & 46 & \\
\hline \multicolumn{2}{|c|}{ 計 } & 42 & 26 & 68 & \\
\hline
\end{tabular}

N.S. : 有意でない

表 3 検査成績と水腎症悪化

\begin{tabular}{|c|c|c|c|c|c|}
\hline 要 & 因 & $\begin{array}{l}\text { 水婜症 } \\
\text { 非悪化 }\end{array}$ & $\begin{array}{l}\text { 水䁂症 } \\
\text { 悪化 }\end{array}$ & 計 & 検定結果 \\
\hline \multirow{2}{*}{ 膀胼変形 } & なし & 21 & 8 & 29 & \multirow{2}{*}{ N.S. } \\
\hline & あり & 21 & 18 & 39 & \\
\hline \multirow{4}{*}{$\begin{array}{l}\text { VUR } \\
\text { グレード }\end{array}$} & $\mathrm{Ia}+\mathrm{Ib}$ & 7 & 3 & 10 & \multirow{4}{*}{ N.S. } \\
\hline & $\mathrm{IIa}+\mathrm{IIb}$ & 14 & 9 & 23 & \\
\hline & III & 13 & 11 & 24 & \\
\hline & IV & 8 & 3 & 11 & \\
\hline \multirow{2}{*}{ 術前水腎症 } & なし & 20 & 18 & 38 & \multirow{2}{*}{ N.S. } \\
\hline & あり & 22 & 8 & 30 & \\
\hline \multicolumn{2}{|c|}{ 計 } & 42 & 26 & 68 & \\
\hline \multicolumn{2}{|c|}{ Areflexia } & 22 & 15 & 37 & \multirow{2}{*}{ N.S. } \\
\hline \multicolumn{2}{|c|}{ Hyperreflexia } & 11 & 11 & 22 & \\
\hline \multicolumn{2}{|c|}{ 計 } & 33 & 26 & 59 & \\
\hline
\end{tabular}

N.S. : 有意でない
全68例中 26 例 (38\%) に手術後初回の IVP で水腎症 の出現または増悪が認められた。一側手術の44例の中 で水腎症の悪化がみられたのは15例 $(34 \%)$ であった。 その内訳は手術した尿管の水腎症悪化が10例, 反対側 の尿管に悪化がみられたものが 2 例, 両側の水腎症悪 化が認められたものが 3 例であった。両側手術 24 例中 4 例に片側のみの悪化が， 7 例に両側の悪化が認めら れ，合計すると11例（46\%）であった。一側手術例と 比べると両側手術例の方に水腎症悪化が多いが有意で は無かった.VUR 初回手術例と再手術例の水腎症悪 化率はいずれも $38 \%$ であった。 ステント留置例と非留 置例の水腎症悪化率はそれぞれ $36 \%$ と $39 \%$ で有意差は 無かった。

2）術前検査成績と水腎症悪化（表 3)

膀胱変形は全体の過半数にみられた. 変形あり39例 中に水腎症悪化例の占めるの割合は18例 $(46 \%)$ で, 変形なし（29例中 8 例， $28 \%$ ）より多いが有意な違い では無かった。逆流の程度からみるとグレードと水腎 症の悪化との関係は認められなかった。術前より水腎 症があったのは 30 例でその内 8 例に水腎症増悪がみら れ，術前に水腎症が無かった38例中18例に水腎症が出

図 1 Areflexia 例の膀胱尿道内圧測定成績. 棒グラ フ内の数はデータ例数を示す.
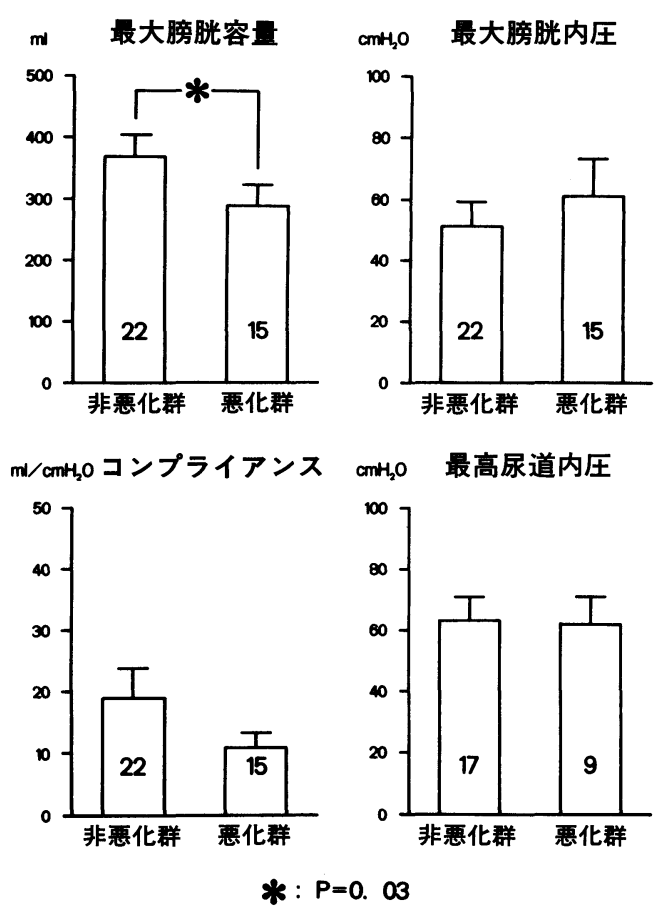
表 4 コンプライアンスと水腎症悪化(Areflexia)

\begin{tabular}{c|c|c|c|c}
\hline コンプライアンス & 水腎症非悪化 & 水腎症悪化 & 計 & 検定結果 \\
\cline { 1 - 4 }$>10 \mathrm{ml} / \mathrm{H}_{2} \mathrm{O}$ & 13 & 4 & 17 & \multirow{2}{*}{$\mathrm{P}=0.05$} \\
\cline { 1 - 4 }$\leqq 10 \mathrm{ml} / \mathrm{H}_{2} \mathrm{O}$ & 9 & 11 & 20 & \\
\cline { 1 - 4 } 計 & 22 & 15 & 37 & \\
\hline
\end{tabular}

現した．前者より後者の方が比率は高いが有意差は無 かった。術前の膀胱内圧測定データが存在した59例を みると，37例が areflexia で22例が hyperreflexia で あった。このタイプの違いによる水腎症悪化例の割合 に違いは無かった。

3）膀脱尿道内圧測定成績と水腎症悪化

膀胼内圧測定，尿道内圧測定で得られた各パラメー ターについて水腎症悪化群と非悪化群で比較した。 Areflexia の37例についてみたのが図 1 である。悪化 群の最大膀脱内圧 $61 \pm 12 \mathrm{cmH}_{2} \mathrm{O}$ (平均土標準誤差) は 非悪化群の $51 \pm 8.0 \mathrm{cmH}_{2} \mathrm{O}$ より高いが有意では無 かったが，悪化群の最大膀胼容量 $(290 \pm 32 \mathrm{ml})$ は非悪 化群 $(370 \pm 35 \mathrm{ml})$ に比べ有意に小さかった $(\mathrm{p}=0.03)$. コンプライアンス值については, 悪化群 $(11 \pm 2.4 \mathrm{ml} /$ $\left.\mathrm{cmH}_{2} \mathrm{O}\right)$ は非悪化群 $\left(19 \pm 5.1 \mathrm{ml} / \mathrm{cmH}_{2} \mathrm{O}\right)$ より低かっ たが有意な差では無かった。そこで明らかに低コンパ ライアンスと考えられる $10 \mathrm{ml} / \mathrm{cmH}_{2} \mathrm{O}$ 以下の膀胱の 割合を見たのが表 4 である。37例中20例（54\%）が10 $\mathrm{ml} / \mathrm{cmH}_{2} \mathrm{O}$ 以下であったが, 水腎症悪化はこの低コン プライアンス膀腃に有意に多かった $(\mathrm{p}=0.05)$ ，最高 尿道内圧に関しては両群間に有意差は無かった（非悪 化群 $63 \pm 8.4 \mathrm{cmH}_{2} \mathrm{O}$ ：悪化群 $62 \pm 9.5 \mathrm{cmH}_{2} \mathrm{O}$ ).

Hyperreflexia の場合（図 2), 最大膀脱容量（非悪 化群 $190 \pm 32 \mathrm{ml}$ : 悪化群 $180 \pm 37 \mathrm{ml}$ ), 最大膀胼内圧 (非 悪化群 $75 \pm 7.5 \mathrm{cmH}_{2} \mathrm{O}$ : 悪化群 $\left.69 \pm 9.3 \mathrm{cmH}_{2} \mathrm{O}\right)$, 最高 尿道内圧（非悪化群 $74 \pm 7.9 \mathrm{cmH}_{2} \mathrm{O}$ : 悪化群 $64 \pm 14$ $\mathrm{cmH}_{2} \mathrm{O}$ )のいずれも非悪化群と悪化群で有意な違いは 認められなかった. Hyperreflexia 全例を Areflexia 全 体と比較してみると最大膀胼容量は有意に小さく $(180 \pm 23 \mathrm{ml}: 340 \pm 24 \mathrm{ml}, \mathrm{p}=0.0001)$, 最大膀胱内圧は 有意に高かったが $\left(72 \pm 5.6 \mathrm{cmH}_{2} \mathrm{O}: 55 \pm 6.8 \mathrm{cmH}_{2} \mathrm{O}\right.$, $\mathrm{p}=0.02)$, 最高尿道内圧については差が無かった $\left(70 \pm 7.4 \mathrm{cmH}_{2} \mathrm{O}: 62 \pm 6.3 \mathrm{cmH}_{2} \mathrm{O}\right)$.

4）膀胱内圧曲線タイプ別でみた水腎症悪化

手術条件や検査成績の個々の要因は，全体でみると 水腎症の悪化に関係無かった（表 $2 ， 3$ ）。そこで areflexia と hyperreflexiaに分けて検討した。一側対
図 2 Hyperreflexia 例の膀胱尿道内圧測定成績。棒 グラフ内の数はデータ例数を示す.
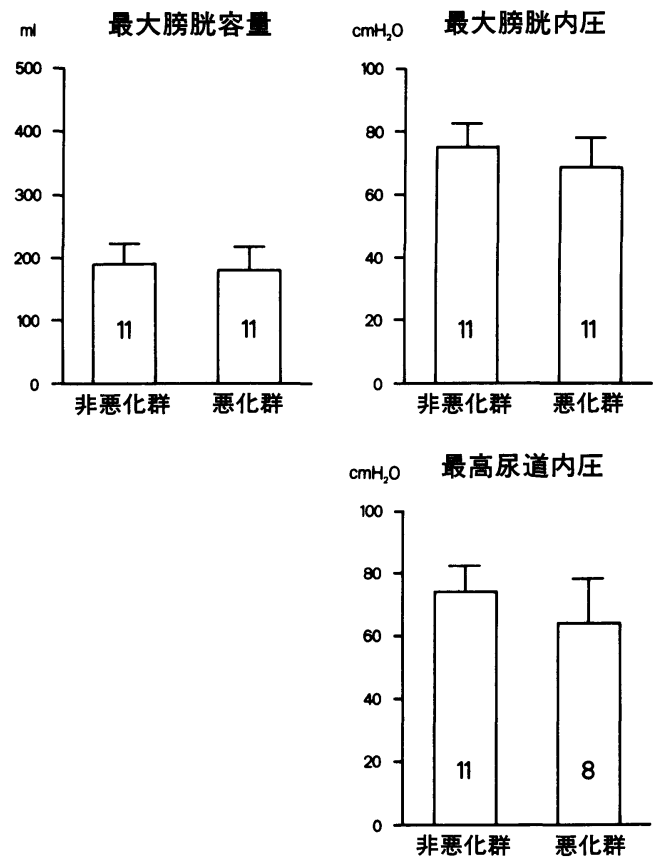

表 5 膀胱内圧曲線タイプ別でみた水腎症悪化

\begin{tabular}{|c|c|c|c|c|c|}
\hline タイプ & 膀胖変形 & $\begin{array}{l}\text { 水腎症 } \\
\text { 非悪化 }\end{array}$ & $\begin{array}{c}\text { 水腎症 } \\
\text { 悪化 }\end{array}$ & 計 & 検定結果 \\
\hline \multirow{2}{*}{ Areflexia } & なし & 11 & 3 & 14 & \multirow{2}{*}{$\mathrm{P}=0.06$} \\
\hline & あり & 11 & 12 & 23 & \\
\hline \multirow{2}{*}{ Hyperreflexia } & なし & 7 & 5 & 12 & \multirow{2}{*}{ N.S. } \\
\hline & あり & 4 & 6 & 10 & \\
\hline 計 & & 33 & 26 & 59 & \\
\hline
\end{tabular}

N.S. : 有意でない

両側手術, ステント留置の有無, 術前の水腎症の有無, 逆流の程度についてはいずれのタイプにおいても有意 な関係は無かったが，膀胱変形については違いがみら れた（表 5 )。すなわち areflexia の場合，膀胱変形の ないものに水腎症非悪化例が，変形ありに悪化例が多 くみられる傾向にあった $(p=0.06)$.

5）VUR 再発抢よび水腎症の転帰

手術後の観察期間中 10 例にVUR 再発が認められ た。手術直後の水腎症の出現あるいは増悪とVUR 再 発の関係をみたのが表 6 である，水腎症非悪化群の再 発率は17\%（7/42），悪化群のそれは12\%（3/26）であ り有意差は無かった。 
水腎症非悪化群中22例に術前から水腎症があったが （表 3 ），その転帰は現在まで持続しているものが 2 例， 持続脱落 4 例，軽快したが残っているもの 1 例，軽快 脱落 1 例，完全に消失したものが14例であった。この 消失に要した期間は $1 \sim 14$ 力月, 平均 5 カ月であった。 水腎症悪化群 26 例の転帰は脱落 1 例, 持続 1 例，持続 脱落 2 例，術前と同程度に戻ったのが 1 例，完全消失 が21例であった，完全消失期間は $2 \sim 30$ カ月，平均 8 カ月であった。 この值は非悪化群のそれと比べると長 いが有意差は無かった。なお VUR 再発例はその時点 で脱落としている，手術前後とも水腎症は認められな かったが，最後まで追跡できなかった 2 例も除外する と，最終的に水腎症が残った割合は $9 \%(5 / 56)$ であっ た。

IVP 上腎形態の悪化の認められた例は無かった。

\section{考 察}

今回の調査では全体でみると膀胱変形, VUR グ レード, 術前水腎症, 膀胱内圧曲線タイプや手術の諸 要因のどれも単独要因としては水腎症悪化と有意な関 係は無かった、ステントを使用していない症例の方が 水腎症の悪化が多いと予測されたが，実際は変わらな かった。手術直後は尿管膀胱吻合部の浮腫による閉塞 が起こり ${ }^{9)}$ ，両側手術例ではステントが無いと無尿に なることさ光ある。しかしこのような急性期炎症反応 は初回 IVP 時には拉さまっていること, 既にステント は拔去されておりこれによる尿管閉塞防止効果はキャ ンセルされていることから，ステントの有無の影響は 無かったと思われる。

我々の知る限り尿流動態検査成績と尿管膀脱新吻合 術術後の水腎症との関係を調べた報告はないようであ る. 本検討により areflexia 例に限ると最大膀脱容量 の小さいもの, $10 \mathrm{ml} / \mathrm{cmH}_{2} \mathrm{O}$ 以下の低コンプライアン 不膀脱が術後水腎症の悪化を来たし易いといらことが 初めて明らかになった。一方 hyperreflexia 例は水腎 症悪化と最大膀胱容量, 最大膀胱内圧との間に明らか な関係は無かった。手術法がなんであれ膀胼壁の肉柱 形成, cellules 形成, 線維化, 肥厚といった器質的変化 が VUR 防止術の成否や合併症増加に関係することは 容易に想像される. Areflexia の場合排尿筋の器質的 変化が膀胱容量やコンプライアンスの減少として直接 反映されるが, hyperreflexia では排尿筋の反射が様々 な膀胼容量時に様々な強さで起こりらるため, 膀脱内 圧測定上のパラメーターが膀胖の器質的変化を反映す るとは限らない。このため両タイプで相違が生じたと
推察される.

Kobayashi らは脊髄形成不全患者に招いてVUR の発生に関倸するのは最高尿道閉鎖圧であり，排尿筋 の hyperreflexia やコンプライアンスは有意相関が無 かったと述べている77. また岡村らや櫻井らは機能的 下部尿路閉塞例に逆流防止術を必要とする VUR が多 く見られたと報告している(1)3). 今回の検討では両タイ プとも水腎症悪化群と非悪化群間で最高尿道内圧は有 意差がみられなかった。 神経因性膀胼における VUR 発生と術後水腎症を同列に論じることはできないが, 当センターではまず最初に括約筋切開術や間欠導尿な ぞによって低圧排尿管理に変兄, VUR の消失や予防 を計っていることが理由の一つかもしれない(5)8).

膀脱内圧曲線タイプ別で検討してみると, areflexia 例の膀胼变形の有無に関してのみ相違がみられたのは 興味深い(表 5 ). Hyperreflexia 例では膀胱の過活動 の要因が強いため膀胼変形が術後水腎症に与える影響 が相対的に低いのに対し, areflexia 例は排尿筋が低活 動であるので膀胼変形が水腎症悪化要因として強調さ れていると解することが可能である．別の見方をすれ ば, areflexia の膀胱変形なしの悪化率21\%(3/14) は, 変形ありの $52 \%(12 / 23)$, hyperreflexia の変形なしの $42 \%$ （5/12）や变形ありの60\%（6/10）より明らかに 低く, areflexia かつ膀胼変形のない症例が水腎症悪化 を最も来たしにくいといえる。

全手術に対するVUR 再発率は15\%（10/68）であっ た。術後水腎症悪化の有無で分けて比較してみると(表 6 ), 有意差は無いが水腎症悪化群の方が若干再発が少 なかった。これは尿管の膀胱粘膜下トンネル部が長い ほど逆流防止効果は確実になる反面，通過障害を括こ すリスクは増すということの現れかもしれない。

小児 VUR 3,527 例の尿管膀脱形成術にともなら合 併症を集計した結果，逆流の再発や尿管通過障害は 各々 $4 \%$ であり, IVP 上の腎杯鈍円化や腎実質菲薄化 の進行も 4 \%に認められたが，これらの多くは尿管通

表 6 水腎症悪化と VUR 再発

\begin{tabular}{c|c|c|c|c}
\hline VUR 再発 & なし & あり & 計 & 検定結果 \\
\hline 水腎症非悪化 & 35 & 7 & 42 & \multirow{2}{*}{ N.S. } \\
\cline { 1 - 3 } 水腎症悪化 & 23 & 3 & 26 & \\
\cline { 1 - 3 } 計 & 58 & 10 & 68 & \\
\hline
\end{tabular}

N.S. : 有意でない 
過障害ではなく逆流や感染の持続によるものであっ た ${ }^{10)}$. また最終的に再手術を要するような尿管通過障 害は, 諸家のレポートを総合すると $2 \%$ 以下であっ $た^{9)}$. 神経因性膀胱の場合, 手術後 $36 \%$ の尿管に閉塞が みられ再手術を含む治療を要したとするものもある が11)，その後の文献によると尿管通過障害の合併率は $0 \sim 7 \%$ 範囲である(12)12)13). 腎形態に関しては悪化 例が全く無かったというものもあれば1)12)，VUR 再発 や尿管通過障害により $10 \%$ 余りに悪化がみられたと報 告するものもあり, 経過観察期間や集計方法の違いも あり幅がみられるが，これらに対し再手術を行らこと により改善がみられている214).

今回我々の経過観察期間中 VUR 再発例を除けば, 術前ないし術後発生した水腎症の大半は消失し (91\%)，尿管通過障害のため再手術を要した例は無く, 腎形態の悪化も認められなかった。神経因性膀脱だか らといって晚期合併症として再手術を要するような尿 管通過障害が多い訳ではなく，そのことで手術成功率 が劣るものでないと結論される。㐬た初回手術と比べ ると再手術時の膀胱の条件は悪いと思われるが，水腎 症の悪化率に違いは無かった。このことはVUR の再 発に際して特に術後水腎症を懸念して再手術を躊躇す る必要はないことを示唆する。

原発性 VUR と違って神経因性膀胼による二次性 VUR は, 手術でVURを治療できたとしても原因であ る神経因性膀胱そのものの管理が悪ければ，再び VUR や水腎症の再発が起こり得る運命にあるとい兄 る. したがって間欠導尿，抗コリン剂や $\alpha$ ブロッカー の使用，括約筋切開術などによる低圧排尿の維持と尿 路感染の治療, 予防が本症治療の基本であることに変 わりはな(2)588112)。

\section{結 語}

神経因性膀胱によるVUR に対して行われた尿管膀 胼新吻合術の合併症である水腎症に注目し，その出現 または増悪に関わる要因を検討した。

1）68例の手術直後 26 例（38\%）に水腎症の出現，ま たは増悪がみられた。

2）全体でみると膀胱変形, VUR グレード, 術前水 腎症, 膀脱内圧曲線タイプ (areflexia, hyperreflexia), 手術要因のいずれも水腎症悪化と関係無かった。

3) Areflexia 例の場合, 膀胱変形, 最大膀胱容量, コンプライアンスの 3 要因が水腎症悪化に関係してい た.すなわち水腎症悪化群に膀胱変形例や $10 \mathrm{ml} / \mathrm{cmH}_{2}$ $\mathrm{O}$ 以下の低コンプライアンス例が多く, 膀胱容量は有
意に小さかった，最大膀脱内圧や最高尿道内圧は関係 無かった。

4) Hyperreflexia 例に打いては, 膀胼変形, 最大膀 胼容量, 最大膀胱内圧, 最高尿道内圧のどれについて も水腎症悪化群と非悪化群で違いは無かった。

5）一部（9\%）に水腎症が残存したが，その後増悪 したり再手術を要した例はなく，それ以外は水腎症が 消失した。腎形態の悪化は 1 例も無かった。原発性と 同様に神経因性膀胱に打いても術後水腎症の長期予後 は良好である。

\section{文献}

1）櫻井 勗, 中村正広, 辻本幸夫, 营尾英木：小児神 経因性膀腅に伴 5 VUR の治療一逆流防止術の検 討一. 泌尿紀要, 31，257-263，1985.

2) Brereton, R.J., Narayanan, R. and Ratnatunga, C.: Ureteric re-implantaion in the neuropathic bladder. Br. J. Surg., 74, 1107-1110, 1987.

3）岡村 清, 夏目 修, 山本雅司, 百瀬 均, 末盛 毅, 塩見 努, 山田 薰: 二分春椎に起因する神経 因性膀胱に伴 万VUR についての考察. 泌尿紀要, 34, 95-101, 1988.

4) Goerdin, A., Wyndaele, J.J. and De Sy, W.A. Ureteroneocystostomy in the neuropathic bladder associated with high-grade reflux. Eur. Urol., 20, 29-32, 1991.

5）原岡正志, 岩坪映二, 柳田俊彦：神経因性膀脱に対 する膀胼尿管逆流防止術53例の臨床的検討。西日 泌尿，53，1041-1046，1991.

6）新島瑞夫：文部省科研総合研究 VUR 研究班に打 ける非閉塞性 VUR の追跡調査成績について。 日 泌尿会誌，68，854-855，1977.

7) Kobayashi, S., Shinno, Y., Kakizaki, H., Matsumura, K. and Koyanagi, T.: Relevance of detrusor hyperreflexia, vesical compliance and urethral pressure to the occurrence of vesicoureteral reflux in myelodysplastic patients. J. Urol., 147, 413-415, 1992.

8）高山一生, 妹尾康平, 熊澤净一, 岩坪暎二：小児神 経因性膀胱に伴う VUR の治療. 西日泌尿, 46, 1303-1308, 1984.

9) Gibbons, M.D. and Gonzales, E.T. Jr.: Complications of antireflux. Surgery. Urol. Clin. North Am., 10, 489-501, 1983.

10) Marshall, S., Guthrie, T., Jeffs, R., Politano, V. and Lyon, R.P.: Ureterovesicoplasty: Selection of patients, incidence and avoidance of complications. A review of 3,527 cases. J. Urol., 118, 829-831, 1977.

11) Hirsch, S., Carrion, H., Gordon, J. and Politano, V.: Ureteroneocystostomy in the treatment of 
reflux in neurogenic bladders. J. Urol., 120, $552-554,1978$.

12) Kass, E.J., Koff, S.A. and Diokno, A.C.: Fate of vesicoureteral reflux in children with neuropathic bladders managed by intermittent cath- eterization. J. Urol., 125, 63-64, 1980.

13) Kaplan, W.E. and Firlit, C.F.: Management of reflux in the myelodysplastic child. J. Urol., 129, 1195-1197, 1983.

（1993年 3 月 31 日受付， 1994年 1 月 28 日受理） 